\title{
Pre-Marriage Pregnancy in Islamic Law Compilation
}

\author{
Erma Wulandari ${ }^{*}$, Hilal Malarangan ${ }^{2}$, Ermawati Ermawati ${ }^{3}$
}

1 Islamic Family Law Department, Postgraduate, Institut Agama Islam Negeri Palu 2 Islamic Family Law Department, Postgraduate, Institut Agama Islam Negeri Palu

${ }^{3}$ Islamic Family Law Department, Postgraduate, Institut Agama Islam Negeri Palu

\begin{abstract}
The aim of this paper is to discuss pre-marriage pregnancy in Islamic Law Compilation. This study is literature review research with qualitative method. The data was gathered through content analysis and written material. Data analysis was analyzed using grounded theory approach and thematic building. The results showed that the formulation of article 53 paragraph (1), of the Islamic Law Compilation, a pregnant woman can be married with the man who impregnated her. And article 53 provides a solution for pregnant women who are married to men who impregnate them. While in relation to the status of child, it is considered legal because there has been a legal marriage; however, in the sharia, the status of child is still debated. Regarding the issue of which opinion is used, it can be seen from which opinion is greater for the benefit of society.
\end{abstract}

\section{ARTICLE \\ INFORMATION}

Keywords:

Pre-marriage pregnancy, Islamic law, compilation 


\section{Introduction}

According to Sharia, marriage is an agreement between a man and a woman with the aim of belonging to each other by establishing a safe and prosperous household. ${ }^{1}$ As social beings, humans cannot live alone. They are related to each other in order to get offspring as the next generation. Individuals in the household are called families. ${ }^{2}$

The purpose of marriage in Islam is to form a family that is harmonious. In law No.1 of 1974, marriage is a physical and spiritual bond between a man and a woman as husband and wife which aims to build a happy family. ${ }^{3}$ Therefore, in a marriage it is necessary to have inner and outer love between husband and wife, ${ }^{4}$ so that married life will last long and be maintained.

This is also stated in the Islamic Law Compilation article 2, namely marriage according to Islam is marriage, which is a very strong contract to obey Allah's command. ${ }^{5}$ This is in accordance with the nature of humans as honorable beings to maintain lineage according to the Qur'an. Efforts to maintain this honor

1 Mardani. Ushul Fiqh, (Jakarta: PT. Raja Grafindo Persada, 2014) 21.

2 Yusuf, Psikologi Perkembangan Anak dan Remaja (Bandung: PT Remaja Rosdakarya Offset, 2004), 138

3 Hasbullah Bakri. Kumpulan lengkap Undang-undang dan Peraturran Perkawinan di Indonesia, (Jakarta : Djambatan, 1985) 3th Edition, 3

4Abdul Manan, Aneka Masalah Hukum Perdata Islsam di Indonesia, (Jakarta; Kencana, 2014),2.

12 Ministry of Religious Affairs, Kompilasi Hukum Islam (Bandung : Humaniora Utam Press, 1991), 18. are by fostering the relationship between humans properly. ${ }^{6}$

Offspring are a mandate from Allah, which is a valuable asset that serves as successor generation. The problem arises if there is a child born outside marriage. This will lead civil cases in the future.

Pregnant marriage itself is a problem that is included in the dissenting opinions. For this reason, the discussion will focus on the legal basis and the arguments used.

According to the law, a woman who is pregnant out of marriage can be married to the man who impregnated her. This can take place without waiting for the birth of her child first. ${ }^{7}$ By conducting a marriage with pregnant woman, there is no need for remarriage after the child is born. ${ }^{8}$

The solution offered in the article 53 in the Compilation of Islamic Law is very interesting to study, because based on cultural change, this legal solution could be used as the legality of adultery. Because of that, in this study, the article 53 of the Compilation regarding pregnant marriage will be examined using the maslahah approach, either from the Compilation or Islamic law in general. ${ }^{\circ}$ Because by using this

${ }^{6}$ Law Number 1 Year 1974 Article 6 : (1) and Islamic Law Compilation, Article 16 : (1)

7Ibid.

${ }^{8}$ Ibid.

${ }^{9}$ Muslih, I., Nurdin, N., \& Marzuki, M. (2020). Effectiveness of Marriage Services Through Information System Management (SIMKAH) at Palu City Religious Court INTERNATIONAL JOURNAL OF e-ISSN: $2715-4580$ p-ISSN: 2715-8268 
approach, the purpose of the formation of pregnant marriage in the Compilation and its relation to Sharia will be revealed.

\section{Literature Review}

\subsection{The Compilation of Islamic Law}

Compilation is the activity of collecting materials on certain from various sources or books scattered in different places. This is carried out by taking from various sources of several different authors to be summarized in a particular book with the aim of making it easier to find the materials or regulations needed to solve a problem. ${ }^{10}$

From the above explanation, it can be said that Islamic Law Compilation or $\mathrm{KHI}$ is an activity to collect rules in Islamic law related to several problems, where the results can be used as a guide for the judges in the religious court in Indonesia. Meanwhile, if viewed from the perspective of legal products, KHI is a collection of Islamic law provisions that are written and compiled regularly. ${ }^{11}$

The idea of writing a compilation of Islamic law arose after several years the Supreme Court had been developing the judicial techniques of the Religious Courts. ${ }^{12}$ This coaching task is also based

CONTEMPORARY ISLAMIC LAW AND SOCIETY, 2(1), 20-36. Indonesia, 11

${ }^{10} \mathrm{Abdurrahman}$, Kompilasi Hukum Islam di

11 A. Hamid S. Attamimi, "ketentuan Komppilasi Hukum Islam Dalam Sisitem Hukum Nasional, Suatu tinjauan dari Sudut Teori Perundang-undangan di Indonesia, (Jakarta : Gema Insani Press, !996), 152

12Basiq Jalil, Pengadilan Agama di Indonesia, Cet. ke-1 (Jakarta: Kencana Prenada Media Group, 2006), 109. on the Constitution No. 14 of 1970 regarding the principal powers of the judiciary.

During the development of the Religious Courts, the Supreme Court views several weaknesses. For example, Islamic laws applied within the Religious Courts tend to confuse due to the differences in the opinions of ulama in determining a law in a judicial environment. As a result, Law No.1 of 1974 concerning marriage was ratified, that applies to all citizens. ${ }^{13}$

\subsection{The Position of the Compilation of Islamic Law in Indonesia}

KHI is legalized through a legal instrument in the form of Presidential Instruction No. 1 of 1991 dated 10 June $1991,{ }^{14}$ and the Decree of the Minister of Religion No. 154 of 1991 dated 22 July 1991.15 According to A. Hamid S. Attamimi, before the Presidential Instruction No. 1 of 1991 was enforced, some people want KHI to be stipulated by a Presidential Decree or Government Regulation, and some even want it to be established by law. ${ }^{16}$

Thus, KHI has an important

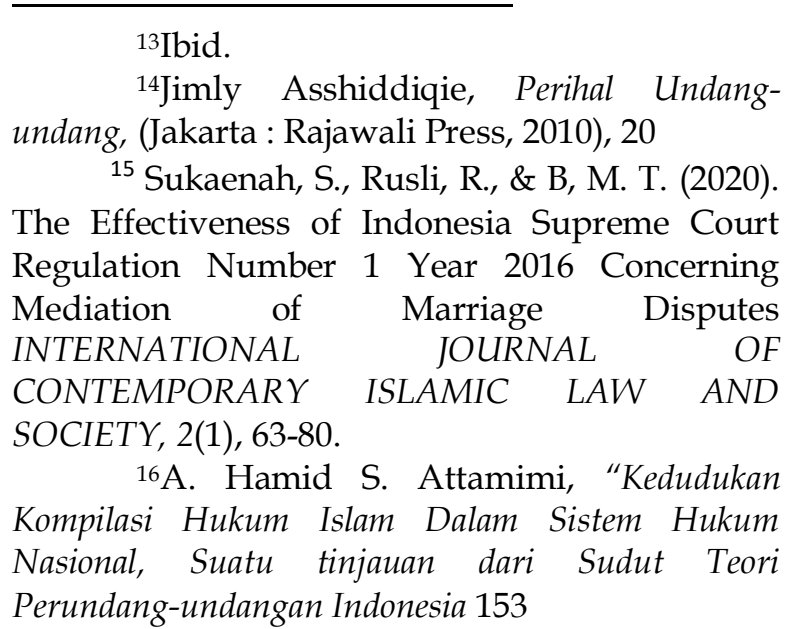

e-ISSN: 2715-4580 p-ISSN: 2715-8268 
position in the Indonesian legal system. it is a reflection of the social will of its makers. Its presence is in line with certain social, cultural and political motives of the legitimator, in this case, the New Order political regime.

Thus, ideologically, KHI is at the midpoint between the religious paradigm and the state paradigm. In the religious paradigm, Islamic law must be implemented by Muslims as a whole, regardless of time and space. Its application in social life becomes a sacred religious mission. In other words, Islamic law is under the control of state law by considering plurality, religion, ethnicity, race, and class. The result of the interaction between these two different paradigms is a concrete form of state politics against Islamic law in Indonesia. Therefore, KHI is the only Islamic material law that obtains political and juridical legitimacy from the state.

Although, in practice, $\mathrm{KHI}$ is used as a guideline by the Religious Courts in deciding cases in the field of Islamic civil laws, because the basis for its enforcement is only based on the Presidential Instruction, and its nature is only as a performance, then in fact the legal force of KHI is very weak.

In conclusion, $\mathrm{KHI}$ based on the Presidential Instruction does not have permanent legal force, or if it has legal force, but is limited to only one person or one particular agency given the instruction so that its existence cannot be used as a positive written law that binds and forces all citizens. In addition, when viewed from the perspective of its enforcement, $\mathrm{KHI}$ is facultative and not imperative, ${ }^{17}$ that is, there is still room for options to do or not do it at all; so that it is not binding.

Definition of Marriage during Pregnancy

Marriage during Pregnancy is defined as the case of a woman who becomes pregnant before entering the marriage contract, then marries the man who impregnated her. ${ }^{18}$ The Qur'an does not differentiate between adultery, incest, or prostitution. All intercourse between a man and a woman outside of marriage is adultery. The Qur'an views the act of pregnancy outside of marriage as a heinous act (fakhisyah).

The prohibition of adultery is the main prohibition in the concept of violating the principle of maintaining honor. However, the prohibition also applies to all kinds of acts that lead to adultery. The prohibition of adultery boils down to maintaining the honor and dignity of humans as honorable beings. In order for humans to remain respectable in their sexual activities, Islam makes marriage laws so that the fullfilment of their biological needs is carried out legally and with dignity. ${ }^{19}$

The stipulation of marriage in the Quran is a door to close adultery and protect offspring, and form a good family. In turn, a good family will become a medium to prevent conflict and

17 Jaenal Aripin, Jejak Langkah Peradilan Agama di Indonesia, 99

18Zainuddin Ali, Hukum Perdata Islam di Indonesia, Cet. I. (Jakarta : Sinar Grafika, 2006), 45.

${ }^{19}$ Ridwan, Kekerasan Berbasis Gender Cet. 1, (Purwokerto: Pusat Studi Gender, 2006),149150.

e-ISSN: 2715-4580

p-ISSN: 2715-8268 
tension in society. ${ }^{20}$ Therefore, efforts made to reform the issues of Islamic family law from social movement's perspective and Islamic law. ${ }^{21}$

\section{Pregnancy Marriage from Islamic Law Perspective}

The Islamic law scholars agree on the permissibility of marrying an adulterous woman for those who commit adultery; thus, the marriage between a man and a woman whose pregnancy is itself is legal. ${ }^{22}$ In Islamic law, adultery is considered a very cursed act and is considered a crime. This opinion was agreed by the scholars, except for the difference in punishment. According to some scholars regardless of the perpetrator, whether it is done by an unmarried person or a married person, as long as the intercourse is outside the framework of marriage, it is called adultery, and is considered an act against the law. Nor does it reduce the value of the conviction, even if it is done voluntarily or consensually. Even though no one feels aggrieved, adultery is seen

20 Rusli Rusli, "The Role of Family in Preventing Social Conflict in Society From Islamic Perspectives," HUNAFA: Jurnal Studia Islamika 17, no. 1 (2020): 108-122.

21 See more detailed Rusli Rusli, "An Analysis of Islamic Feminism in Indonesia: Reconstruction of Islamic Legal Issues on Gender Relations," Hunafa: Jurnal Studia Islamika 3, no. 1 (2006):

$1-12$,

https://www.jurnalhunafa.org/index.php/huna fa/article/view/239.; Rusli Rusli, Islamic Feminism: Responses of Muslim Feminists to Gender Inequality in Indonesia (Palu: Irshed Press, 2006).

22Wabah Zuhaily, Al-Figh Al-Islam Wa Adillatuhu, (Damsyiq, Dar-Al-Fikr, 1989), vol. VII., 48. by Islam as a gross violation of sexuality, and is forbidden in all circumstances. ${ }^{23}$

\section{Methodology}

This research is library research. ${ }^{24}, 25$ Library research serves to understand the general view of jurists in answering the problem of pregnant marriage cases and also their relation to the Compilation of Islamic Laws that apply in Indonesia. Therefore, the data collected is in the form of books, journals, magazines, related to the legal issue of pregnant marriage.

This study uses a normative and juridical approach, which uses data from the Qur'an and hadith ${ }^{26}$ as well as the principles of fiqh and ushul figh, with explanations of the opinions of the scholars of Imam Schools relating to the issues under study so that they can understand the purpose of the law in depth.

\section{Result and Discussion}

\subsection{Benefit to Women}

\footnotetext{
${ }^{23}$ Rahmat Hakim, Hukum Pidana Islam, (Figh Jinayah) Untuk IAIN, STAIN, PTAIS, (Bandung: Pustaka Setia, 2000), 69.

${ }^{24}$ Muhammas Nazir, Metode Penelitian, (Bogor: Ghalia Indonesia, 1988), 54

${ }^{25}$ Salam, K., \& Nurdin, N. (2015). AlMishbah: Jurnal Ilmu Dakwah dan Komunikasi. Al-Mishbah: Jurnal Ilmu Dakwah dan Komunikasi, 11(1), 47-64.

${ }^{26}$ Iqbal, M., Rusli, R., \& Musyahidah, M. (2019). Management Strategies of Professional Zakat Funds for Mustahiq Family Welfare By Amil Zakat Body INTERNATIONAL JOURNAL OF CONTEMPORARY ISLAMIC LAW AND SOCIETY, 1(1), 39-51.
} 
Pregnant marriage is a marriage that is preceded by the pregnancy of a woman before a legal marriage or marriage contract is carried out, either with the man who impregnated her or the man who did not impregnate her. There is controversy over Article 53 of the KHI regarding pregnant marriage. There are those who support, and some who refuse. Opinion that refuses to say that the existence of this article will provide legalization of adultery.

The permissibility to marry pregnant in KHI article 53 is a combination of customary law and religious law. The combination is intended to confirm that the provisions of Islamic law are closer to people's lives. Such attitude can be stated in an expression "Islamizing customary law at the same time together with efforts to bring customary law closer to Islamic teachings." 27 With the combination of Islamic law and customary law, it is hoped that it will generate normative values in terms of sociology and philosophy, a sense of justice and humanity.

Article 53 does not provide sanctions or penalties for the perpetrator of adultery, but instead provides a solution to the person who impregnated them. As a result of that adultery, a person who commits adultery immediately gets married. In fact, it is not uncommon for the marriage contract to be carried out when the woman is

27M. Yahya Harahap,Informasi Materi Kompilasi Hukum Islam, Mempositifkan abstraksi hukum Islam, $2^{\text {nd }}$ Edition. (Jakarta: Logos Wacan a Ilmu, 2000). 22. pregnant because of an adulterous relationship, with various purposes, such as covering up the disgrace of the woman's family or because the woman's family is afraid that the man who impregnated her has run away or is not responsible, because it is not Rarely, a man who impregnates a woman out of wedlock will run away and are not responsible. ${ }^{28}$

This contradicts jurisprudence, which explains that married adulterers were hit 100 times and stoned, and unmarried adulterers were beaten 100 times and exiled for 1 year. ${ }^{29}$

Eventhough article 53 adheres to logical reasons and can be used as a legal basis to be applied in the life order of Indonesian society, that it is permissible for a pregnant woman to marry a pregnant woman only with a man who impregnated her. In article 53, it is explained about the permissibility of marrying a pregnant woman, but it does not abort the status of adultery for the perpetrator.

In fact, Hanafi and Shafi'i scholars argue that it is legal to marry a pregnant woman outside of marriage to a man who does not impregnate her. The reason is that the woman is not a woman who is forbidden to marry, so something that is haram (namely adultery) cannot prohibit what is lawful (namely marriage), and

\footnotetext{
28Mohammad Ali Hasan, Pedoman Hidup Berumah Tangga Dalam Islam (Jakarta: Siraja Prenada Media Group, 2006), 253-254.

${ }^{29}$ Muhammad Imam Asy-Syaukani, Nailul Authar, (trans. Adib Bisri Mustafa), (Semarang: As-Syifa, 1994), 550.

e-ISSN: $2715-4580$ p-ISSN: 2715-8268
} 
also the woman is not in a legal marriage. ${ }^{30}$

The impact of this opinion is that if a woman who has become pregnant because of adultery wants to be married, but the man who impregnated her is unknown or does not want to be responsible, it is permissible for any man who is willing and ready to marry that woman. However, this opinion must be put in an 'emergency' position, in the sense that this opinion is a last resort after an attempt is made to marry the pregnant woman to the man who impregnated her.

If it is impossible to marry the man who impregnated her, or if the guardian and her extended family are not willing to marry him, or it could be in the condition that a woman is a victim of rape, who certainly would not want the man who impregnated her, then this opinion can be used.

It is important to note is that article 53 is applied only to pregnant women who are at the time of their pregnancy, and are not in a marriage bond with any man, either a virgin or a widow whose iddah period has ended. Thus, the pregnancy is confirmed as a result of adultery or rape. Otherwise, this article does not apply, even though her pregnancy occurred as a result of adultery with another man who was not her husband or even because she was raped. This means that the pregnancy is still considered a biological result with her legal husband, unless her husband

\footnotetext{
${ }^{30 H u z e m a h}$ Tahido Yanggo, Fikih Perembuan Kontemporer (Bogor; Ghalia Indonesia, 2010), $1^{\text {st }}$ Edition, 60
}

denies the pregnancy for various reasons, then the husband may commit li'an to his wife. Even though the husband denies his wife's pregnancy, this article 53 still cannot be applied to the woman, in the sense that she cannot be married to the man who impregnated her because at that time she was in a marriage bond with her husband.

This problem is very complex indeed; On the one hand, the permissibility of a pregnant woman to get married is to save the life status and fate of the baby, so that after birth, the babby gets the same rights and prevents herself from discriminatory treatment. But on the other hand, the permissibility for pregnant women to get married can cause harm, namely an increase in the rate of adultery which can destroy the fabric of community life.

If the pregnant woman is married to a man who impregnated her before her child was born, then based on KHI article 99, the child is a legal child, with the following reasons: ${ }^{31}$

1. Children born in or as a result of a legal marriage

2. The child who is legally conceived by the husband and wife outside the womb and is born by the wife

Thus, a woman who is pregnant outside of marriage can be married to a man who impregnated her, as well as with a man who did not impregnate her. The goal is to maintain balance and order in social life, protect the survival of pregnant women, and maintain the survival of the babies they are carrying.

${ }^{31} \mathrm{KHI}$, Article 99.

e-ISSN: $2715-4580$ p-ISSN: 2715-8268 
This article benefits to both women and men. First, children born have a father, namely the husband of the mother. Second, men are aware of their responsibilities, so they can think a lot more about impregnating a woman outside of marriage. ${ }^{32}$ The benefit referred to in this article 53 is in the framework of maintaining the continuity of the biological fetus that is already alive in the woman's womb, so that she can be married to the man who impregnated her.

However, if the man who married her was not married, then there is a serious debate; on the one hand, this is not a benefit because the man seems to admit the child that is not produced by him, but on the other hand this is a choice of harm that is lighter than having to burden the child forever with status which he bears as a child out of wedlock, because his mother was not married before his birth. Thus, the purpose of article 53 is to choose a less severe harm or bad impact in accordance with a legal maxim:

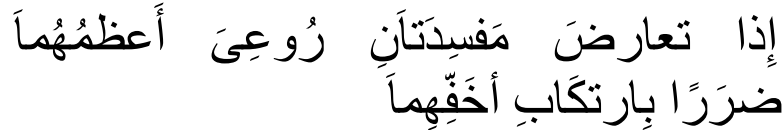

"If there are two contradictory damages (mafsadah), then the concern is the damage (mafsadah) which is (the result) greater, by (way of) doing the lesser the damage (mafsadah)" ${ }^{33}$

\footnotetext{
${ }^{32}$ Hamdan Rasyid, Interview, 31 May 2017, Lihat http:/ / dhitamenulis.blogspot.co.id/2018/02/das ar-hukum-nikah-akibat-zina-sistem.html, Accessed 23 October 2019

33 Ahmad bin Muhammad az-Zaqra', Syarh al-Qawai'id al-Fiqhiyyah, (Damaskus : Dar al-
}

Thus, article 53 aims to avoid the negative impact that will be suffered especially by women and children, as they are ones who suffer the most. And, this article is also an excuse for a woman who is impregnated to sue the man who impregnated her to take responsibility by marrying her.

\subsection{Benefit to Children}

The descent of children born out of wedlock is linked to his mother, and they inherit from the mother. However, children born out of wedlock do not get inherited property from their biological father, because their lineage is cut off in accordance with KHI Article 100. However, there is a solution to solve this problem, namely through grants (hibah). In addition, there is another solution, that is, Fatwa ${ }^{34}$ of MUI fatwa Number 11 of 2012 regarding the position of the child resulting from adultery and the treatment of him. In this fatwa, some provisions are stipulated:

1. Children resulting from adultery do not have a family relationship, marriage guardian, heir, sustenance from the man who impregnated their mother.

2. Children resulting from adultery do only have a family relationship,

Qalam, 1989), cet. III, 201. See also Shalih bin Ghanim as-Sadlan, Al-Qawaid al-Fighiyyah al-kubra wa Ma Tafarra'a anha, (Riyadh : Dar Balansiyah, $1417 \mathrm{H}), 527$

34 For the study of fatwa, see more detailed Rusli Rusli, "TIPOLOGI FATWA DI ERA MODERN: DARI OFFLINE KE ONLINE," HUNAFA: Jurnal Studia Islamika 8, no. 2 (2011): 269-306. 
marriage guardian, heir, from the their mother and their mother family.

3. The children resulting from adultery does not bear the sin of adultery committed by the person who caused their birth.

4. Adulterers are subject to hadd law by the competent authority in the interest of protecting the legal offspring.

5. The government has the authority to impose punishment (ta'zir) on adulterers who cause the birth of a child, by obliging them to:

a) Fulfill the needs of their child.

b) Give their property after they die through obligatory will (wasiat wajibah).

6. The punishment referred to in number 5, which aims to protect the children, not to legalize the child's lineage with the man who caused their birth.

In Article 186, Compilation of Islamic Law, it is stated that: "Children born outside of marriage only get inheritance from their mother and their mother's family". This means that they are not entitled to inheritance from their father. However, through a will (wasiat), the child can obtain a share of the inheritance from the biological father, if the biological father does indeed state in the will before death that the child receives part of the inheritance he left behind. However, the part of the inheritance from the will should not be more than one-third of the inheritance, in order to protect the rights of the main heir.

A will (wasiat) is a release of inheritance that is carried out after someone's death. Basically, a will is an act that is done willingly under any circumstances. Therefore, there is not will in the Islamic law that must be carried out by way of a judge's decision. ${ }^{35}$ The distribution of inheritance to children born outside marriage is the same as the distribution of legal children as regulated in the Islamic Law Compilation. However, for legitimate children, the distribution applies if the inheritance is from the father and mother. Unlike children born outside marriage, the distribution only applies to inheritance from their mother. In principle, the share of boys is greater than girls. This is based on the provisions in Article 176 Compilation of Islamic Law.

Children born outside marriage only have an inheritance relationship with their biological mother. Therefore, it is necessary to have a legal breakthrough in this regard, namely through hibah (grants) and wasiat (wills). In KHI, it is stated that:

"Hibah is the giving of something voluntarily and without reward from someone to another person who is still alive to have." 36

Islamic scholars argue that the limit of hibah is no more than one-third of the inheritance (after being taken for the cost of organizing the body and paying off debts), and is addressed to non-heirs. And this must be done without anyone's permission. If hibah turns out to exceed one third of the inheritance, according to the opinion of most scholars, it is

35Ibid 273
36Islamic Law Compilation, Articel 171 huruf (g).

e-ISSN: 2715-4580 p-ISSN: 2715-8268 
considered valid, but it must obtain permission from the heirs. If some heirs allow and some other heirs do not allow it, then what is given is only the right of the heirs who allow it.

The implementation of wasiat wajibah (obligatory wills) to the siblings who are actually born outside legal marriage in the context of maintaining the integrity of the family, when viewed from a benefit perspective, need to be considered and in concordance with the purpose of Islamic teachings, namely fulfilling a sense of justice. This has provided a solution that is considered sufficient to provide justice, and giving a portion of the inheritance to the children born outside marriage is deemed as a fair and wise act.

\section{Conclusions}

From the above explanation it can be concluded that marriage of a pregnant woman can be with the man who impregnated her, and the status of children outside marriage is considered legally valid because a legal marriage has occurred, although in discourse of Islamic law, the status is still debatable. In this context, it is necessary to see a larger opinion that is beneficial to society. Giving property to children born outside of marriage, because they do not get the inheritance of their biological father, can be done through grants and wills.

\section{REFERENCES}

Abdul M. Mujieb, dkk. Kamus Istilah Fiqh, Jakarta: Pustaka Firdaus, 2002.
Abdullah ibn Muhammad ibn Qudamah, Al-Mughni, juz VIII, (Ttp, Dar AlManar, 1368 H), 181. Dapat juga dilihat dalam Abdul Qadir Audah, al-tasyri al-jinaiy al-Islami, Juz II, Beirut: Dar-Al-kitab Al-'Arabi,tth.

Abdurrahman, Kompilasi Hukum Islam Di Indonesia, Cet 5. Jakarta: Cv. Akademika Pressindo, 2007.

Adz-Dzahabi, Kitab al-Kaba'ir (Jakarta: Syirkah Dina Mutiara Berkah Utama, tth.

Al-Ghazali, Al-Mustasfa min 'Ilm alUsul. Tahqiq Abdullah Mahmud Muhammad Umar. Lebanon: Dar al-Kutub al-Ilmiyyah, 2010.

Ali M. Hasan, Masail Fiqhiyyah alHaditsa, Cet ke 4. Jakarta : PT. Raja Grafindo Persada, 2000.

Ali Mohammad Hasan, Pedoman Hidup Berumah Tangga Dalam Islam, (Jakarta: Siraja Prenada Media Group, 2006.

Ali Mohammad Hasan, Pedoman Hidup Berumah Tangga Dalam Islam, (Jakarta: Siraja Prenada Media Group, 2006.

al-Ragib al-Ashfahani, Mu'jam Mufradat al-Faz Alquran, (Beirut: Dar alKutub al- Ilmiyah, 2013.

Amien Husein Nasution, Hukum Kewarisan, Suatu analisis komparatif pemikiran mujtahid dan kompilasi hukum Islam, Jakarta: Raja Grafindo Persada, 2012.

Amin Muhammad Suma, Hukum Keluarga Islam Didunia Islam, Jakarta: PT Raja Grafindo Persada, 2005. 
Ash-Shabuni, Rawa'i al-Bayaan Tafsir Al-Ahkam min Al-Quran, Jakarta: Dar al- Kutub al Islamiyah, 2001.

Asmawi, Perbandingan Ushul Fiqh, Jakarta: Amzah, 2011.

Asyhari Abdul Ghofar, Zina dan Perkawinan Sesudah Hamil, Cet 3. Jakarta: Andes Utama, 2000.

Azhar, Ahmad Basyir, Hukum waris Islam, edisi revisi, Yogyakarta: UII Pres, 2001.

Bakri, Hasbullah. Kumpulan lengkap Undang-undang dan Peraturran Perkawinan di Indonesia, cet. Ke III .Jakarta : Djambatan, 1985.

Basiq Jalil, Pengadilan Agama di Indonesia," Cet. ke-1 Jakarta : Kencana Prenada Media Group, 2006.

Beni Ahmad Saebani, Fiqh Mawaris, Bandung: Pustaka Setia, 2009.

Buletin Dakwah Islam, Syariat Islam dalam Rahmat untuk semua Umat, Edisi 056. Jakarta : Syahab Hizbut Tahri t.th.

Chuzaimah T. Yanggo Dan Hafiz Anshary (Eds), Problematika Hukum Islam Kontemporer 1 Jakarta : Pustaka Firdaus, 2008.

Dedi Supriadi, Fikih Munakahat Perbadingan (dari tekstual sampai legislasi), Cet 1 . Bandung: $\mathrm{Cv}$ Pustaka Setia, 2011.

Dep Dikbud. Kamus Besar Bahasa Indonesia, Jakarta : Balai Pustaka, 1994.

Departemen Agama Repubik Indonesia Terjemahan Al-Jumanatul 'Ali AlQuran Bandung : CV.Penerbit JART, 2005.
Direktorat Pembina Peradilan Agama, Kompilasi Hukum Islam di Indonesia, cet. ke-3 Jakarta : 2003.

Ensiklopedia Alquran, Kajian Kosa Kata, Jakarta: Lentera Hati, 2007.

Ghazali, Abdul Rahman Fiqh Munakahat. Jakarta: Kencana, 2003. Habiburrahman, Rekonstruksi Hukum Kewarisan Islam Di Indonesia, Cet. III; Jakarta: Kencana Prenada Media Group, 2011.

Halim, Abdul Hasan, Politik Hukum Islam di Indonesia Kajian Posisi Hukum Islam Dalam Politik Hukum Pemerintahan Orde Baru dan Era Reformasi, Cet. ke-1 Tt : Badan Litbang dan Diklat Departemen Agama RI, 2008 .

Halim, Abdul Hasan, Tafsir AL-Ahkam, Jakarta: Kencana, 2006.

Hamka, Tafsir Al-Azhar Juz XVII, Jakarta: Pustaka Panjimas, 1983.

Haroen, Nasrun. Ushul Fiqh 1. Jakarta: Logos Wacana Ilmu, 1997.

Hasan Cik Bisri, Peradilan Agama di Indonesia, Cet. ke- 4 Jakarta : PT.Raja Grapindo Persada, 2003.

Hasan, M. Ali. Masail Fiqhiyah alHaditsah. Jakarta: PT. Raja Grafindo Persada, 1995.

Hilman Hadikusuma, Hukum Waris Adat, Bandung: PT. Cipta Aditya Bhakti, 2003.

Husnaini Muhammad Makhluf, Kalimat Alquran Tafsîr waBayân, Qahirah: Dar al-Qalam, 1956.

Ibn al-Qayyim al-Jauziyyah, I'lâm alMuwaqqi'în 'an Rabb al-'Âlamîn, Kairo: Dâr al-Hadîts, 1425 H/2004 M, Juz ke-3. 
Ibrâhîm Mustafa, dkk., al-Mu'jam alWasît , Tahrân: al-Maktabah al'Ilmiyyah, t.th.), Juz ke-1.

Imam al-Syafi'i Abu Abdullah Muhammad Bin Idris, Mukhtasar Kitab Al-Umm Al-Fiqh, edisi bahasa indonesia ringkasan Kitab al-umm, diterjemahkan oleh Imron Rosidi, dkk, buku ke 2 Cet. Ke 1. Jakarta: Pustaka Azam, 2004.

Iqbal, M., Rusli, R., \& Musyahidah, M. (2019). Management Strategies of Professional Zakat Funds for Mustahiq Family Welfare By Amil Zakat Body INTERNATIONAL JOURNAL OF CONTEMPORARY ISLAMIC LAW AND SOCIETY, 1(1), 39-51.

Irfan Nurul, Nasab dan Status Anak dalam Islam. Jakarta: Amanah, 2012.

Jamâl al-Dîn Muhammad ibn Mukarram ibn Manzûr al-Ifrîqi,Lisân al'Arab, Riyad: Dâr 'Âlam al-Kutub, 1424 H/2003 M, Juz ke-2.

Kasir Ibnu, Tafsîr Ibnu Kasir, diterjemahkan oleh Salim Bahreisy, Said Bahreisy, Surabaya: PT Bina Ilmu, 2005.

Luciana lanson, Dari Wanita Untuk Wania, Surabaya: Usaha Niaga, 2003, 459.

M. Bahri Ghazali, Konsep Ilmu menurut al-Ghazali, Suatu Tinjauan Psikologik-Paedagogik, Jakarta: Pedoman Ilmu Jaya, 2001.

M. Bahri Ghazali, Konsep Ilmu menurut al-Ghazali; Suatu Tinjauan Psikologik-Paedagogik, Jakarta: Pedoman Ilmu Jaya, 2001. Hukum Pidana Islam Jakarta: Sinar Grafika, 2007.
M. Maslehuddin, Islamic Yurisprudence and The Rule of Necessity and Need, terj. A. Tafsir, Hukum Darurat dalam Islam. Cet-1. Bandung: Pustaka, 1985.

M. Yahya Harahap,Informasi Materi Kompilasi Hukum Islam, Mempositifkan abstraksi hukum Islam, Cet 2. Jakarta: Logos Wacana Ilmu, 2000.

Mahd-Idris Ramulyo, Hukum

Perkawinan, Hukum Kewarisan, Hukum Acara Peradilan Agama dan zakat menurut hukum Islam, Cet ke1. Jakarta: Padat Karya Agung, 1991.

Mahmud Yunus, Kamus ArabIndonesia,Jakarta: Yayasan

Penyelenggara

Penterjemah/Penafsiran

Al-

Qur'an, 2001.

Manan Abdul, Aneka Masalah Hukum Perdata Islsam di Indonesia. Jakarta; Kencana, 2014.

Manan, Abdul, Aneka Masalah Hukum Perdata Islam di Indonesia, Jakarta: Kencana, 2006.

Manzhur Ibnu, Lisan al-Arab, II, Beirut: Dar al-Fikr, t.th., 516; Hans Wehr, A Dictionary.

Manzhur Ibnu, Lisan al-Arab, II, Beirut: Dar al-Fikr, t.th., 516; Hans Wehr, A Dictionary.

Mardani. Ushul Fiqh, Jakarta : PT. Raja Grafindo Persada, 2014.

Millah Saiful, Dilema Hukum Perkawinan Wanita Hami, Tanggerang Selatan : Young Progressive Muslim.

Modul Keluarga Bahagia Sejahtera. Jakarta : BP-\$ Persat, 1998. 
Mohammad Ali Hasan, Pedoman Hidup Berumah Tangga Dalam Islam, Jakarta: Siraja Prenada Media Group, 2006.

Muhajir Noeng, Metode Penelitian Kualitatif, Edisi II Cet. VIII; Yogyakarta: Rake Sarasin, 1983.

Muhammad bin Husain bin Hasan AlJizani, Mu'alim Usul Al-Fiqh (Riyad\}: Dar Ibnu Al-Jauzi, 2008.

Muhammad ibn Abi Bakr ibn 'Abd alQâdir al-Râzi, Mukhtâr al-Sihâh, Beirut: Dâral-Kitâb al-'Arabi, 1979.

Muhammad Imam Asy-Syaukani, Nailul Authar, (terjemah Adib Bisri Mustafa), Semarang: As-Syifa, 1994.

Muhammad Imam Asy-Syaukani, Nailul Authar, (terjemah Adib Bisri Mustafa), Semarang: As-Syifa, 1994.

Muhammad Imam Asy-Syaukani, Nailul Authar, terjemah Adib Bisri Mustafa), Semarang: As-Syifa, 1994.

Muhammad Jawad Mughniyah, Fiqih Lima Mazhab, Cet. 4. Jakarta: Lentera Hati, 2000.

Muhammad Jawwad Ridla, Tiga Aliran Utama Teori Pendidikan Islam, terj. Mahmud Arif, Yogyakarta: Tiara Wacana, 2002.

Muhammad Murtadâ al-Husaini alZabîdî, Tâj al-'Arûsmin Jawâhir alQâmûs, Beirut: Dâr al-Fikr, 1414 H/1994 M, Juz ke-4.

Muhammad Mutawali Sya'rawi, Tafsîr Sya'rawî, Jilid 9, Jakarta: PT Khazanah Nusantara Agung, 2011. Muhammad Said Ramadân al-Bûti, Dawâbit Mashlahah fi al-Syarîah
al-Islâmiyyah, Beirut: Mu'assasat al-Risâlah, 1421 H/2000.

Muhammad, Abi Abdillah Ibn Yazid alQazwini, Sunan Ibn Majah, Juz 2, Bairut: Daral-Fikr, tt

Muhammadibn Abi Bakr ibn 'Abd alQâdir al-Râzi, Mukhtâr al-Sihâh, Beirut: Dâr al-Kitâb al-'Arabi, 1979.

Mukhsin Jamil (ed.), Kemaslahatan dan

Pembaharuan Hukum Islam, Semarang: Walisongo Press, 2008.

Munawwir, Ahmad Warson, Kamus alMunawwir, Surabaya : Pustaka Progresif, 1997.

Muslih, I., Nurdin, N., \& Marzuki, M. (2020). Effectiveness of Marriage Services Through Information System Management (SIMKAH) at Palu City Religious Court INTERNATIONAL JOURNAL OF CONTEMPORARY ISLAMIC LAW AND SOCIETY, 2(1), 20-36.

Musthofa Rahman, Anak Luar Nikah Status Dan Implikasi Hukumnya, Jakarta : Penerbit Atmaja, 2003.

Nina Surtiretna, Bimbingan Seks Pandangan Islam dan Medis, Cet ke 1. Bandung: PT. Remaja Rosdakarya, 2000.

Nurul Irfan, Nasab dan Status Anak dalam Hukum Islam Jakarta: Amzah, 2013.

Qadir, Abdul Audah, al-tasyri al-jinaiy al-Islami, Juz II, Beirut : Dar-Alkitab Al-'Arabi, tth.

Qadir, Abdul Audah, Ensiklopedi Hukum Pidana Isla, Jakarta: Kharisma Ilmu, 2007.

Rahmad Rosyadi, Rais Ahmad, Formalisasi Syariat Islam Dalam Persfektif Tata Hukum Indonesia, e-ISSN: 2715-4580 p-ISSN: 2715-8268 
Cet. ke-1 Bogor : Penerbit Ghalia Indonesia , 2006.

Rahmat Hakim, Hukum Pidana Islam, (Fiqh Jinayah) Untuk IAIN, STAIN, PTAIS, Bandung: Pustaka Setia, 2000.

Ridwan, Kekerasan Berbasis Gender Cet. 1, Purwokerto: Pusat Studi Gender, 2006.

Rofiq, Ahmad, Hukum Perdata Islam di Indonesia Edisi Revisi, Jakarta: Rajawali press, 2013.

Rofiq, Ahmad, Hukum Perdata Islam Di Indonesia, Jakarta: Raja Grasindo Persada, 2013.

Rusli, Rusli. "The Role of Family in Preventing Social Conflict from Islamic Perspective." HUNAFA: Jurnal Studi Islamka 17, no. 1 (2020): 108-122.

Rusli, Rusli. "An Analysis of Islamic Feminism in Indonesia: Reconstruction of Islamic LegalIssues on Gender Relations." HUNAFA: Jurnal Studia Islamika 3, no. 1 (2006): 1-12.

Rusli, Rusli. Islamic Feminism:Responses of Muslim Feminists to Gender Inequality in Indonesia. Palu: Irshed Press, 2006.

Rusli, Rusli. "Tipologi Fatwa di Era Modern: Dari Offline ke Online." Hunafa: Jurnal Studia Islamika 8, no. 2 (2011): 269-306.

Said Agil Husin Al-Munawar, Membangun Metodologi Ushul fiqh. Jakarta: PT. Ciputat Press, 2014.

Salam, K., \& Nurdin, N. (2015). AlMishbah: Jurnal Ilmu Dakwah dan
Komunikasi. Al-Mishbah: Jurnal Ilmu Dakwah dan Komunikasi, 11(1), 47-64. Samsul Nizar, Filsafat Pendidikan Islam; Pendekatan Historis, Teoritis, dan Praktis, Jakarta: Ciputat Press, 2002. Sandu, Siyoto, dan Ali Sodik Muhammad. Dasar Metodologi Penelitian. Literasi Media Publishing, 2015.

Sarmin Syukur, Sumber-sumber Hukum Islam, Surabaya: Al-Ikhlas, 1993.

Slamet Abidin dan H. Aminuddin, Fiqh Munakahat, Cet. Ke 2. Bandung : CV Pustaka Setia, 1999. 31.

Slamet Abidin dan H. Aminuddin. Fiqh Munakahat, Cet. Ke 1. Jilid Ke 1. Bandung: CV Pustaka Setia, 1999.

Sukaenah, S., Rusli, R., \& B, M. T. (2020). The Effectiveness of Indonesia Supreme Court Regulation Number 1 Year 2016 Concerning Mediation of Marriage Disputes INTERNATIONAL JOURNAL OF CONTEMPORARY ISLAMIC LAW AND SOCIETY, 2(1), 63-80.

Syamsu Andi Alam dan Fauzan, Hukum

Pengangkatan Anak Perspektif IslamJakarta: Kencana, 2008.

Syamsubahri Salihima, Perkembangan pembagian warisan dalam hukum Islam dan Implikasinya pada Pengadiloan Agama, Jakarta: Predanamedia Group, 2016.

Syarifuddin Amir, Hukum Perkawinan Islam di Indonesia, Jakarta: Kencana, 2007.

Syarifuddin Amir, Ushul Fiqh 2. Jakarta: Ken cana, 2008.

Tihami H.M.A, dkk. Fiqih Munakahah kajian fiqih lengkap. Jakarta : PT. Raja Grafindo Persada, 2009. 
Tim inti adalah H. Bustanul Arifin, H.Md Kholid, H.Masrani Basran, HM. Yahya Harahap, H. Zaeni Dahlan, H.A Wasit Aulawi, H. Muchtar Zarkasy, Amiroeddin Noer, $\mathrm{H}$. Marfuddin Kosasih.

Tim Redaksi Fokus Media, Komplikasi Hukum Islam, (Bandung : Fokus Media, 2005.

UU No. 1 Tahun 1974 Tentang Perkawinan

Wabah Zuhaily, Al-Fiqh Al-Islam Wa Adillatuhu, Damsyiq, Dar-Al-Fikr, 1989 Jilid VII.

Wahab, Abdullah Khallaf, Ilmu Ushulul Fiqh, terj. Noer Iskandar alBansany, Kaidah kaidah Hukum Islam, Cet-8Jakarta: PT. Raja Grafindo Persada, , 2002.

Yahya Abdurahman al-Khatib, HukumHukum Wanita Hamil, (Ibadah, Perdata dan pidana), Cet Ke 1,(Bangil, Al-Izaah, 2003.

Yusuf al-Qaradawi, Madkhal li Dirâsat al-Syarî́ah al-Islâmiyyah, Kairo: MaktabahWahbah, 1990.

Yusuf, Psikologi Perkembangan Anak dan Remaja. Bandung: PT Remaja.

Zainuddin Ali, Hukum Perdata Islam di Indonesia, Cet. I. Jakarta : Sinar Grafika, 2006. 